Daimon. Revista Internacional de Filosofía, Suplemento $n^{\circ} 7$ (2018), pp. 107-123

ISSN: 1130-0507 (papel) y 1989-4651 (electrónico)

http://dx.doi.org/10.6018/daimon/333881

\title{
Fellow Feelings: Fraternity, Equality and the Origin and Stability of Justice
}

\author{
Sentimientos Solidarios: Fraternidad, Igualdad \\ y el Origen y Estabilidad de la Justicia*
}

VÉRONIQUE MUNOZ-DARDÉ***

\begin{abstract}
Resumen: El artículo presenta un análisis del papel que la idea de fraternidad juega en la Teoría de la Justicia de John Rawls. Muchos comentaristas críticos, G.A. Cohen, por ejemplo, han criticado el papel de la fraternidad y su relación con el principio de la diferencia. ("Un mérito adicional del principio de diferencia es que ofrece una interpretación del principio de fraternidad.") El artículo explica el lazo entre el principio de fraternidad de Rawls y el papel de los sentimientos en la Teoría de la Justicia. Se pone en particular el énfasis sobre la tercera parte de la Teoría de la Justicia, que ha recibido menos atención. La idea principal es que, contrariamente a lo que alegan los críticos de Rawls, el sentimiento de solidaridad Rawlsiana presenta una 'utopía realista' con verdadera plausibilidad y que define una política verdaderamente igualitaria.

Palabras clave: Fraternidad, Rawls, Principio de Diferencia, Igualdad, Igualitarismo de la Suerte, G.A. Cohen.
\end{abstract}

\begin{abstract}
This article presents an analysis of the role that the idea of fraternity plays in John Rawls's A Theory of Justice. Many commentators, G.A. Cohen for example, have taken as their target the role of fraternity in understanding the difference principle. ("A further merit of the difference principle is that it provides an interpretation of the principle of fraternity.') The article highlights the neglected connection between Rawls's principle of fraternity and the role of sentiments in A Theory of Justice. I focus, in particular, on the third part of A Theory of Justice, which has received less attention in the secondary literature. The main idea put forward is that, contrary to what his egalitarian critics contend, the Rawlsian conception of fraternity constitutes the most plausible version of this political ideal: one which is properly egalitarian.
\end{abstract}

Keywords: Fraternity, Rawls, Difference Principle, Equality, Luck-Egalitarianism, G.A. Cohen.

Recibido: 07/06/2018. Aceptado: 09/07/2018.

* I am grateful for the helpful suggestions and comments received, in particular, from Victoria Camps, Joan Verges Gifra, Angel Puyol Gonzalez, Tom Sinclair and Mike Martin.

** Véronique Munoz-Dardé is Professor of Philosophy at UCL and also teaches in the Department of Philosophy at UC Berkley (munoz_darde@berkeley.edu \& v.munoz@ucl.ac.uk). Her research is principally in practical reasoning, ethics and political philosophy, as well as in eighteenth century political thought, particularly that of Rousseau and Hume. For a list of recent publications, see https://ucl.academia.edu/VeroniqueMunozDarde. The research which led to this paper was carried out under the aegis of the research group 'Fraternidad, Justicia y Democracia' (Barcelona). 
In a well-known article devoted to the importance of sufficiency, Harry Frankfurt notes in passing the surprising lack of serious exploration of the ideal of fraternity with respect to liberty and equality:

In the Sterling Memorial Library at Yale University (which houses 8.5 million volumes), there are 1,159 entries in the card catalog under the subject heading "liberty" and 326 under "equality". Under "fraternity", there are none. This is because the catalog refers to the social ideal in question as "brotherliness". Under that heading there are four entries! Why does fraternity (or brotherliness) have so much less salience than liberty and equality? Perhaps the explanation is that, in virtue of our fundamental commitment to individualism, the political ideals to which we are most deeply and actively attracted have to do with what we suppose to be the rights of individuals, and no one claims a right to fraternity. It is also possible that liberty and equality get more attention in certain quarters because, unlike fraternity, they are considered to be susceptible to more or less formal treatment. In any event, the fact is that there has been very little serious investigation into just what fraternity is, what it entails, or why it should be regarded as especially desirable. (Frankfurt, 1987, p. 24)

Frankfurt's remarks remain pertinent: the political ideal of fraternity is still elusive, even if the word is often used rhetorically to signal the need for greater social solidarity. It may seem that fraternity does not sit comfortably in the logic of individual rights expressed by liberty and equality, and in general within our current focus on distributive justice. Yet by the time Frankfurt wrote these lines, Rawls had already suggested a possible interpretation of the ideal of fraternity, and perhaps even of a 'right to fraternity'. In this, he was echoing a trend to be found in the French Revolution and throughout the nineteenth and twentieth century: the use of the idea of fraternity to advocate that all citizens and, in particular the most deprived and powerless, should be full participating members of society, sharing in decisions, and in benefits from social cooperation. (See David, 1987 and 1992.)

Rawls's proposal for the ideal of fraternity has met with very little enthusiasm: the only comments I have found which have focused on this aspect of his book have been by egalitarian and communitarian critics. Thus G.A. Cohen claims that the acceptance of inequalities in Rawls's principles is inconsistent with relations of fraternity, and Michael Sandel remarks that the individualistic logic of justice and rights threatens to undermine valuable communal sentiments of fraternity. ${ }^{1}$ The idea of fraternity is not essential to Rawls's central arguments in A Theory of Justice (19712), and he didn't return to it, emphasizing instead the idea of solidarity. However, his proposal is interesting, for three reasons. First, a too commonplace criticism of Rawls's theory is that it is overly individualistic in form, and focused too much on matters of self-interest; were such a criticism valid, then there should be a fundamental conflict between the ideal of fraternity and Rawlsian principles: demonstrating the lack of conflict helps put in its place this form of critique. Second, in articulating explicitly what

1 G. A. Cohen's criticism is developed in a series of articles, the first and the most eloquent of which is (Cohen, 1992), particularly pp. 321-322. See also Sandel (1982, pp. 32-35).

2 Hereafter $A$ Theory of Justice is abbreviated TJ. Pages and quotes are from the 1999 revised edition. 
Rawls must have had in mind in the passing observations on fraternity scattered throughout the text in TJ we can better understand the place of sentiments in a Rawlsian just society. Finally, and ultimately most importantly, Rawls's own position on the question of fraternity goes a long way to answering Frankfurt's challenge: it provides us with at least the contours of the political ideal of fraternity.

In the first section, I sketch briefly Rawls's first comments on fraternity in the chapter on 'The tendency to equality', and the questions they raise. I address the first of my concerns above in the following section: focusing on egalitarian criticisms of Rawls, to the effect that his conception of fraternity is either incoherent or individualistic and selfish, and as a result insufficiently egalitarian; I question whether these criticisms properly understand the role of fraternity in Rawls's theory. The third section is concerned with the second of my concerns: I turn to the role of sentiments in Rawlsian theory in order to outline the role that an ideal of fraternity, and fraternal sentiments, may play within a just state. In this discussion, I emphasize the contrast between sentiments as a basis of political structures and sentiments as instruments of support of just society. This furnishes us with the materials to provide an answer to Frankfurt, and I conclude by briefly outlining what a reasonable understanding of the political ideal of fraternity might consist in.

\section{Rawls, Fraternity and Ties of Sentiment}

Some aspects of Rawls's treatment of fraternity are well-known and have been amply commented on. In this section, I briefly revisit some of these remarks on fraternity in the first part of TJ, highlighting their puzzling structure.

Rawls's initial lines on the ideal of fraternity are notorious: he notes that 'In comparison with liberty and equality, the idea of fraternity has had a lesser place in democratic theory. It is thought to be less specifically a political concept, not in itself defining any of the democratic rights.' Immediately following on from this, Rawls proposes that his difference principle (DP) constitutes a standard of justice that matches the idea of fraternity, and expresses its fundamental meaning from the standpoint of social justice. The 'principle of fraternity', or DP, stipulates that inequalities in the distribution of primary goods are to be 'to the greatest benefit of the least-advantaged members of society'. Put succinctly, Rawls's thought is that the difference principle requires that the fruits of social cooperation in society be channelled to those who are most in need, the worst off among us; and he adds that this is precisely the most natural meaning that we can give to the political ideal of fraternity.

The Difference Principle is one of the key principles for the main political and social institutions of society (the Basic Structure of Society) chosen in an Original Position of equality, where parties are placed behind a Veil of Ignorance. (They do not know their particular conception of the good life, their place in society, class position, social status, race or ethnic group, sex, intelligence, natural endowments, and so forth.) These principles are:

(a) Each person has the same indefeasible claim to a fully adequate scheme of equal basic liberties, which scheme is compatible with the same scheme of liberties for all; and 
(b) Social and economic inequalities are to satisfy two conditions: first, they are to be attached to offices and positions open to all under conditions of fair equality of opportunity; and second, they are to be to the greatest benefit of the least-advantaged members of society (this last clause being the Difference Principle). ${ }^{3}$

Rawls draws a connection early on in TJ, between these principles and the traditional political ideals of liberty, equality and fraternity. He writes:

We can associate the traditional ideas of liberty, equality, and fraternity with the democratic interpretation of the two principles of justice as follows: liberty corresponds to the first principle, equality to the idea of equality in the first principle together with equality of fair opportunity, and fraternity to the difference principle. In this way we have found a place for the conception of fraternity in the democratic interpretation of the two principles, and we see that it imposes a definite requirement on the basic structure of society. (TJ, p. 90, emphasis added)

However, having suggested the idea of a 'definite requirement' imposed by his conception of fraternity, Rawls does not go on to explain what the obligations of fraternity are; rather, he focuses on the kind of sentiments and motivations involved in the idea of fraternity:

The difference principle ... seems to correspond to a natural meaning of fraternity: namely, to the idea of not wanting to have greater advantages unless this is to the benefit of others who are less well off. The family, in its ideal conception and often in practice, is one place where the principle of maximizing the sum of advantages is rejected. Members of a family commonly do not wish to gain unless they can do so in ways that further the interests of the rest. Now wanting to act on the difference principle has precisely this consequence.' (TJ, loc. cit., emphasis added)

This extension of personal sentiments to political motivation is not entirely novel, but it seems deeply suspicious to many readers of Rawls. Are fraternal political sentiments a necessary pre-condition for the principles to work? In other words, do citizens in a Rawlsian society already need to be motivated by fraternal sentiments in order to comply with what the difference principle requires? If such sentiments are an essential requirement on citizens of the just society, why is their role neither discussed nor emphasized before this point in the outline of the theory? If, on the other hand, fraternal feelings are irrelevant to the operation of the principles within just society, why bother to mention them at all in relation to the difference principle? Moreover, the comparison between sentiments among citizens to feelings among family members seems severally problematic. Among other concerns, Rawls seems to be abandoning the division between principles for personal conduct on the one hand, and, on the other hand, principles for the Basic Structure of society: the main institutions of society and their combined actions and policies. Yet that distinction is at the very core of his theory. ('For us the primary subject of justice is the basic structure of society, or more

3 As formulated in (Rawls, 2001, pp. 42-43). Hereafter Justice as Fairness: A Restatement is abbreviated JFR. 
exactly, the way in which the major social institutions distribute fundamental rights and duties and determine the division of advantages from social cooperation.' TJ, p. 6)

Accordingly, some egalitarian, feminist and communitarian readers see the surprising focus on individual sentiments in the paragraphs just quoted of TJ as symptomatic of two fundamental defects of the Rawlsian theory of justice. First, Rawls needs individuals to already share a sentiment of fraternity in order for society to be just; yet his limiting the scope of justice to the manner in which major social institutions distribute fundamental rights and duties is narrowly focused on the legal structure to the exclusion of a fraternal ethos. Second, by so limiting himself to mere background legal justice, Rawls is committed to endorsing injustices which are beyond the scope of the legal structure: in the family, or more generally in individual transactions.

Over the years, Rawls's defenders have responded to these criticisms, emphasizing the plausibility of a division of labour between a just background structure and principles for individuals. Rawlsians have argued that a plausible theory ought to have space both for justice, and for our legitimate individual pursuits and attachments. The justice of background institutions makes fair transactions between individuals possible, and allows people to engage with the partiality of their concerns: their attachments to those they love, their individual intellectual interests, what they value. ${ }^{4}$ However, this form of response leaves untouched the role of sentiments within a Rawlsian society. And this leaves in play a more fundamental concern. For surely, the idea that a society suitably permeated by a fraternal ethos would be more egalitarian, and so more just, seems interesting and plausible. And this invites a further critique of Rawls.

Starting from this possibility, critics have raised a number of questions. The most important concern the very formulation of principles of justice, and in particular the difference principle. Thus critics have pitched Rawls's sentiments against his principles: they claim that his gnomic remarks on fraternity stand in stark contrast to what they see as an endorsement of unjust inequalities through the difference principle. Would people truly motivated by a fraternal concern for the least well off, they ask, model their conduct on a principle which justifies inequalities in wealth and income, or would they affirm a more egalitarian principle? In other words: isn't aligning the political ideal of fraternity with Rawls's difference principle a mistake? A second, related, set of questions have focused on the scope of principles of justice. Why limit the scope of the difference principle just to the basic structure? Some inequalities may be beyond the scope of legal structures, such as gender attitudes in the family, for example. But does this mean that they should be regarded as beyond the scope of justice? Shouldn't principles of justice apply directly to citizens' individual conduct? Surely, critics insist, even after citizens have duly paid their taxes, there are still some fraternal (and sororal) duties demanding that they do what they can for the least well-off. Correspondingly, some authors consider that the least well-off must do their bit, and not claim compensation for inequalities which are the result of choices they are responsible for. The Rawlsian ideal, by focusing on legal structures rather than on principles for individual conduct, this second line of attack concludes, does not give us a correct account either of citizens' responsibilities or of the ideal of fraternity.

4 I have had my say on feminist perspectives in (Munoz-Dardé, 1998). For a Rawlsian take on egalitarianism see (Scheffler, 2003). In a spirit more sympathetic to egalitarian criticisms, see also (Estlund, 1998). 
The most interesting and thorough pursuit of these lines of criticism remains that formulated by G.A. Cohen, to whom I turn in the next section. My focus will be on disentangling internal and external criticisms that are knotted together in this line of thought. In particular, our questions will be: 1) whether Rawls's lines quoted on the ideal of fraternity reveal a tension internal to his theory between the fraternal motivation of individuals who affirm the difference principle and the inequalities allowed by that principle and 2) whether a more plausible principle ought to be formulated to replace the difference principle which does proper justice to the ethos of fraternity. In other words: according to this egalitarian critique, would the correct understanding of the ideal of fraternity be more Rawlsian than Rawls, or instead an alternative to Rawlsian justice?

\section{Cohen's Fraternity: More Rawlsian than Rawls? An Alternative to Rawlsian Justice?}

As anticipated above, G. A. Cohen has more than one line of attack against Rawls's Difference Principle: some of these are addressed to the form and content of principles of justice in Rawls, some to their scope, and some to the problem of (fraternal) motivation prior to the formulation and operation of principles.

One of the earliest arguments pressed by Cohen concerns the distinction between a basic structure to which principles apply and the norms which govern individuals: for Cohen, justice is a virtue which should directly require things of individuals, and is not merely a matter of institutional structure, concerned with redistribution through taxation. (Cohen, 1997) The initial focus of Cohen's egalitarian criticism is on the motivation of individuals and how this accords or conflicts with the ideal of fraternity.

It is worth noting first that Cohen's reading of the Difference Principle takes it to have the function of justifying inequalities. Whereas the spirit in which the principle is written is rather one of clearly imposing severe constraints on existing inequalities. So, for Cohen, what he reads as the justification of inequalities through the Difference Principle is identical to the commonplace point made about market economies: even the least well-off in society receive benefits if the most talented in society are motivated by hefty salaries to be highly productive. Having thus construed the Difference Principle, Cohen comments that it is true that the least well-off would be even worse off if incentives were not given: in that sense, advantages to the best off have been gained in ways which improve the prospect of the least well-off. However, Cohen remarks, if the better off were really motivated by the Difference Principle and a spirit of fraternity, they would not insist in being bribed to be productive, and so the worse off would be even better off:

A society of maximizers with taxation and regulation dictated by the lax difference principle is necessarily preferable from the point of view of the worst off to a laissezfaire society; but in neither society is the conduct of high fliers consistent with the essentially socialist value of fraternity or with motivation informed by the difference principle. Rawls must give up either his approval of incentives to the exercise of talent or his ideals of dignity, fraternity, and the full realization of persons' moral natures. I think the ideals are worth keeping. (Cohen, 1992, p, 322) 
Later on, Cohen returns to the question of motivation and the tension which he finds within Rawlsian theory between the selfish inclinations of well-placed individuals (he calls them 'the talented') who demand higher rewards to be productive and the ideal of fraternity:

Either the relevant talented people themselves affirm the difference principle or they do not. That is: either they themselves believe that inequalities are unjust if they are not necessary to make the badly off better off, or they do not believe that to be a dictate of justice. If they do not believe it, then their society is not just in the appropriate Rawlsian sense, for a society is just, according to Rawls, only if its members themselves affirm and uphold the correct principles of justice.

Apart, then, from the very special cases in which the talented literally could not, as opposed to the normal case where they (merely) would not, perform as productively as they do without superior remuneration, the difference principle can justify inequality only in a society where not everyone accepts that very principle. It therefore cannot justify inequality in the appropriate Rawlsian way. (Cohen, 1997, p. 8)

In sum: Cohen's view is that a more egalitarian society would result if principles of justice were directly motivating individuals. In particular those 'talented' to produce could choose: i) to work hard without special incentives; and ii) to work at occupations which benefit the least well-off. Cohen illustrates this thought, and its radically egalitarian implications for the ideal of fraternity, with the simple example of two brothers:

Two brothers, A and B, are at benefit levels 6 and 5, respectively, in New York, where they live. If they moved to Chicago, their levels would rise to 10 and 6 . If they moved to Boston, they would rise to 8 and 7. Is fraternity, as Rawls means to characterize it, consistent with A proposing that they move to Chicago? If so, it is a thin thing. Or is Rawlsian fraternity strictly maximizing? In that case, Boston is the choice, and, in a feasible set with no bar to redistribution, equality is the result. (Cohen, 1992, p. 322 , emphasis added)

Cohen's alternative proposal to Rawls, focused on how just individuals within a just society might be motivated, and which he suggests may be more Rawlsian than Rawls, seems explicitly focused on the equality of outcomes. The properly fraternal response, for Cohen, is one in which the brothers 'maximize' what fraternity demands, and in which equality is the result. Now, it isn't yet clear how we are to interpret this maximizing conception. At an abstract level, we may puzzle over a conception which tells agents to aim at state of affairs which have as much equality as possible. Cohen seems to conceive the way in which equality in states of affairs polices our actions on a model parallel to that in which utilitarians conceive of the welfare of states of affairs. That is: states of affairs are better or worse in terms of their closeness to perfect equality. To define a ranking of state of affairs from best to worst in virtue of how equal people are presents formal similarities with the consequentialism of utilitarianism, and might be just as controversial. ${ }^{5}$

5 For this point, see my (Munoz-Dardé, 2005) 
Be that as it may, Cohen's proposal is at first more attractive than that: his view is that in a properly fraternal society a more generous distribution would result than Rawls allows for, because there would be less inequalities. However, unlike Rawls's Difference Principle which does not establish any distinction among the worst off, Cohen's egalitarianism is severely constrained: it is only the inequality of those who are worse off through no choice or fault of their own which matters. Cohen's exact proposal is that a properly fraternal society would be luck-egalitarian: it would eliminate, as far as possible, the effects of involuntary inequalities. ${ }^{6}$ Involuntary inequalities are those that do not appropriately reflect the choices of those who suffer them. The idea is that we distinguish between inequalities which are a result of choices agents are responsible for, and inequalities which are the result of bad brute luck. Justice demands that the impact on people of the latter form of inequalities be eliminated, or at least lessened. In other words, Cohen believes that a proper understanding of fraternity should a) focus on the fact that it is bad that some, through no fault or choice of theirs, are worse off than others and b) motivate us to reduce involuntary inequalities.

The ambition that Cohen and other luck egalitarians share is to delineate a responsibility and choice based form of egalitarianism, and it is that form of egalitarianism which Cohen reads off from, or into, the ideal of fraternity. Cohen holds that it is objectionable, at least to some extent, for some to be worse off than others through no fault, or choice, of their own. If one person is worse off than another through no fault or choice of her own, the situation is unfair, and hence that the inequality between the two people is objectionable. This focus on the value of fairness seems well summarized by Larry Temkin's claim that egalitarians 'generally believe that it is bad for some to be worse off than others through no fault or choice of their own. The connection between equality and comparative fairness explains both the importance, and limits, of the "no fault or choice" clause.' (Temkin, 2003, p. 62)

Now, Cohen often presents his own view of fraternity as more Rawlsian than Rawls. Clearly the emphasis on equality, fairness and the fate of the least well-off all seem to echo core Rawlsian concerns. At the same time, Cohen is critical of Rawlsian egalitarianism. How are we to understand the relation between Cohen and Rawls, does the criticism call for an internal revision of Rawlsian accounts of justice, or for an entirely different form of egalitarianism?

There are in fact two ways in which Cohen's luck-egalitarianism relates critically to Rawls: (a) On the one hand, Cohen wishes to formulate a superior form of egalitarianism, free of what is considered problematic in Rawls's theory, namely the insensitivity of the Difference Principle to the distinction between inequalities which are created by voluntary

6 See Cohen $(1989,916)$. The term luck egalitarianism is used by Cohen to characterize his own view, but it is originally coined by Elizabeth Anderson in her (Anderson, 1999) to bundle together a number of egalitarian authors whose views she wished to criticize for their emphasis 'on correcting a supposed cosmic injustice'. Luck egalitarianism, she writes, is 'the view that the fundamental aim of equality is to compensate people for undeserved bad luck - being born with poor native endowments, bad parents, and disagreeable personalities, suffering from accidents and illness, and so forth.' As a result, luck egalitarianism is focused on eliminating 'the impact of brute luck from human affairs'. The focus on involuntary inequalities is the commitment of authors Anderson described as luck egalitarian: principally G. A. Cohen and Ronald Dworkin, but also Richard Arneson, Eric Rakowski, as well as John Roemer. Of those, only G. A. Cohen is happy to borrow the term luck egalitarianism to describe his view, namely that 'accidental inequality is unjust' (Cohen, 2008, p. 8). See my (Munoz-Dardé, 2014), from which the following few paragraphs in the text are retaken, with slight alterations. 
choices and those which are the result of bad brute luck. (b) On the other hand, Cohen's new egalitarianism still has roots in Rawls's original discussion: Rawls's focus on fairness and on 'inequalities which are arbitrary from a moral point of view' is presented as a commitment to eliminating arbitrary inequalities. According to this second reading, Rawls endorses one of the core elements of the luck egalitarianism of Cohen: justice demands that we even out the effects of brute luck. Moreover, Rawls should accept that the very motivation for the Difference Principle, namely the value of fraternity and a concern for the worst-off, is inconsistent with inequalities justified by the difference principle.

Which of these ways of telling the story should we prefer? Is Cohen's conception of fraternity a rival theory to Rawls, or rather a more coherent formulation of the core Rawlsian doctrine? As we shall see in more detail below, Cohen tries to have things both ways. Can he successfully and coherently press both his luck-egalitarianism and his incentives critique?

In Anarchy, State and Utopia, Nozick accuses Rawls of arguing for economic egalitarianism by overemphasizing social contingencies and natural chance, and underestimating the centrality and importance of individual responsibility and autonomy. Luck egalitarians echo and endorse this criticism. Recall that Rawls's Difference Principle stipulates that social and economic inequalities are just if they are to the greatest benefit of the least-advantaged members of society. In so stipulating the Difference Principle, Rawls does not introduce a distinction between inequalities deriving from choices people have voluntarily made, and social and economic inequalities which derive from unchosen features of those who are disadvantaged relative to others.

Picking up and expanding on Nozick's criticism, luck egalitarians such as Cohen complain: i) that the Difference Principle inappropriately rewards those who are responsible for their deficit in primary goods, e.g. those able-bodied who choose not to work, or to work less hard than others, and ii) that the index of primary goods used in the Difference Principle is insensitive to, and fails to compensate for, disadvantages some suffer relative to others through no fault of their own. That is, Rawls accepts as just a distribution in which some are disadvantaged through brute luck, e.g. because they are handicapped or severely ill.

If the focus is on these two complaints, then the best way of interpreting Cohen's emphasis on fraternity is that his account aims at defining an alternative, more robust, form of egalitarianism by accommodating into our principles for distribution such concerns with responsibility for the outcome of one's choices, and with deficits which are the effects of bad brute luck.

However, there are other ways in which Cohen addresses the ideals of fraternity and equality and these contrast and potentially conflict with this first line of criticism. From this other viewpoint, the core concern of luck-egalitarianism (namely, involuntary inequalities) is continuous with Rawls's insistence on fairness and his focus on inequalities which are 'morally arbitrary'. The question Cohen raises is how to reconcile the Rawlsian emphasis on arbitrary inequalities with the exact formulation of Rawlsian egalitarian principles of justice. Cohen's luck egalitarianism seeks to offer such a reconciliation. By demanding that no one be disadvantaged, or advantaged, by arbitrary factors it aims to define an egalitarianism truer to the focus on fairness, and so more Rawlsian than Rawls, so to speak. More precisely, there are two supposed inconsistencies, internal to Rawlsian fraternity principle, that the luck egalitarianism of Cohen aims at resolving: 
i) On the one hand, the Difference Principle is, as mentioned, insensitive to the choice/luck distinction. However, Rawls seems to make use precisely of this distinction when he argues that the system of natural liberty unjustly allows 'natural and social contingencies' to have a strong impact on distribution:

'[I]ntuitively, the most obvious injustice [of that system] is that it permits distributive shares to be improperly influenced by these factors so arbitrary from a moral point of view.' (TJ, pp, 62-63, emphasis added).

ii) On the other hand, Rawls stresses the 'capacity to take responsibility for our ends' and considers unjust to give a greater share of primary goods to those with expensive taste:

'[I]t is regarded as unfair that [those with less expensive taste] should have less in order to spare others from the consequences of their lack of foresight and selfdiscipline.' (Rawls, 1999, pp. 369-370.

This treatment of expensive tastes is read by G. A. Cohen through luck egalitarian lenses thus: 'People with expensive tastes could have chosen otherwise, and if and when they press compensation, others are entitled to insist that they themselves bear the cost 'of their lack of foresight or self-discipline'.' (Cohen, 'On the Currency of Egalitarian Justice', 913)

To these criticisms, both internal and external, we saw that Cohen adds the view that a fraternal, egalitarian ethos should supplement principles of justice: individuals should be motivated to minimize inequalities. We are now in a position to return to Rawls and his considered views on fraternity: in the next section I shall provide an exegesis and defence of his position. Let us however begin with the response to the luck egalitarianism of Cohen.

There is a ready response both to the internal and external criticisms offered to Rawls here. A proper understanding of Rawls's own explanation of the Difference Principle and the importance of fraternity does not require us to move beyond Rawls's own principles to the luck egalitarian position favoured by Cohen. Moreover, Cohen's luck egalitarianism is neither a convincing alternative to Rawls, nor a plausible elaboration of the intuitions which ground political egalitarian movements.

First, Cohen is mistaken to think that he can best Rawls at his own game. How can Rawls's principles, and in particular the principle of fraternity (or rather the Difference Principle), be made consistent with what Rawls himself says about moral arbitrariness, and about natural talents, expensive tastes and self-discipline? Does Rawls rely on premises regarding choice and luck which the formulation of his principles then contradicts? To these questions, Rawlsians briskly retort that Rawls's arguments support his own principles rather than luck egalitarianism. '[T]he best explanation of the fact that Rawls's theory of justice does not respect the distinction between choice and circumstances,' Scheffler writes, 'is that Rawls is not attempting to respect it. He simply does not regard the distinction as having the kind of fundamental importance that it has for luck egalitarians.' (Scheffler, 2003, p. 7)

Let us note that Rawls clearly denies that inequalities which are the result of genetic and social luck are unjust, or that they ought to be eliminated: 'The natural distribution is neither just nor unjust; nor is it unjust that persons are born into society at some particular position. These are simply natural facts. What is just or unjust is the way that institutions deal with these facts.' (TJ, p. 87) He thus distinguishes between his theory and what he calls 
'a principle of redress', that is 'the [luck egalitarian] principle that undeserved inequalities call for redress' (TJ, p, 100). Rawls further explains that 'the difference principle is not of course the principle of redress. It does not require society to try to even out handicaps as if all were expected to compete on a fair basis in the same race.' (TJ, p. 101)

Why, then, does Rawls emphasize the 'moral arbitrariness' of facts such as natural endowments and social factors? Justice, for Rawls, may not demand the elimination of all effects of bad brute luck; nevertheless, he stresses that a society which systematically disadvantages some of its members on the basis of morally arbitrary factors, such as their natural endowments or the social environment in which they are born, is unjust. This type of morally arbitrary discrimination can happen through overt exclusion, but also simply because contingent social factors may happen to favour an ethnic, gender or social group in the distribution of resources. A just society, according to Rawls, addresses these injustices at the outset, by redistributing to ensure for all fair and favourable background conditions.

The priority of fair background conditions and the role of our institutions in insuring that they are in place is thus what lies behind the Rawlsian emphasis on the moral arbitrariness of certain factors. It constitutes an explanation and defence of the Difference Principle, and to the extent that it is here invoked, the ideal of fraternity. To those who claim that they did nothing but work hard without violating anybody's rights, or that they competed in conditions of formal equality of opportunity for positions which required certain talents, and so ought to reap the rewards of their efforts, Rawls responds that 'the kind of limits and provisos that in Locke's view apply to separate transactions of individuals and associations in the state of nature are not stringent enough to ensure that fair background conditions are maintained.' (JFR, 53)

A just society for Rawls is not one that meets luck-egalitarian requirements, but rather one in which each person is given the opportunities to develop their abilities, and can do so with the guarantee of fair equality of opportunities with others similarly talented and inclined. What matters is not that the consequences of bad brute luck be as far as possible eliminated, nor that life chances be evened out (which, among other things, would require the abolition of the family: see TJ, p, 448 and Munoz-Dardé, 1998), nor a fortiori that our expensive tastes, however acquired, be satisfied in the same measure as that of others. What matters is that all have enough resources to satisfy their interest in pursuing a good life.

In sum, then, there is no internal tension of the sort identified by luck egalitarians in the Rawlsian account. Nor, pace Cohen, is there any need to re-incorporate individual responsibility into that story. In brief, all individuals have two types of responsibilities: first to contribute to maintaining favourable background social circumstances; second, to make a sensible use of their share of primary goods, without imposing unreasonable demands on others.

This may settle the internal question of consistency within Rawls's own text: his appeal to fraternity should not be seen as inconsistent with the work he sets the Difference Principle to. But that doesn't yet address the more fundamental question: does he properly address the concerns bound up in our thoughts about fraternity? Are luck egalitarians truer to our intuitive ideals of fraternity and equality than Rawls?

Certainly Cohen offers no compelling case for this. By comparison with a view focused on compensating people for undeserved bad luck, Rawlsian theory is in fact more theoretically ambitious. Instead of the main emphasis on choice and luck, it aims at finding 
room for the multiple values which a well-ordered society must attend to: respect for persons, needs, opportunities, fairness, solidarity, fraternity, and so on. Politically, its perspective on individual responsibility aims at providing a feasible utopia. It does not ask society to aim at the compensation of all disadvantages that derive from unchosen features, all accidental inequalities (something that cannot be fully delivered anyway). Nor does it have the sometimes implausibly harsh consequence that people should bear the full price of their choices, and be denied compensation for disadvantages that result from these choices.

The Rawlsian account constitutes a multifaceted theoretical take on the political ideals of equality and fraternity. In line with these ideals, it explains and motivates the need to eliminate many types of unjust inequalities. Moreover, a Rawlsian society is prepared to repair inequalities which are not purely the result of brute luck. Contrary to the contentions by luck egalitarians, a Rawlsian society measures up entirely to the standards of political egalitarianism in its distributional and social policies. Indeed, once one reflects on the concerns of political egalitarianism, a Rawlsian society arguably gets closer to their ends than any society guided by luck egalitarian policies would.

\section{Fraternity, Equality, and Rawlsian Sentiments}

However, even if a fraternal society is not luck egalitarian, it may remain true that a fraternal sentiment, or motivation, is missing from the Rawlsian picture, and that would be the kernel of truth in Cohen's critique. We saw earlier that Cohen has the following thought: if the Difference Principle encourages people with abilities and drive, the 'talented', to demand higher rewards than others in order to be productive, then it encourages them to act moved not by fraternity, but rather by self-interest. What the 'talented' demand is to be substantially better paid than others in order to be productive. In so doing they are formally complying with the letter of the Difference Principle: the least well-off are better off than they would be if the talented worked less productively: say because of a trickle-down effect. But at the same time the 'talented' flout the 'natural meaning' attributed by Rawls to fraternity: that of 'not wanting to have greater advantages unless this is to the benefit of others who are less well off.' (See Cohen 1982, pp. 8 and 16ff.)

Notice that this complaint of an internal tension does not need to focus on inequalities as such, but rather on plight of the badly off, and on the kind of fraternal sentiments, or sentiments of benevolence that the better off should have if moved by the spirit of the different principle. (Recall Cohen's example cited above of the two brothers facing the move to Chicago or to Boston.)

As mentioned earlier, there are at several aspects to this objection against Rawls's treatment of fraternity. We can distinguish between (i) the view that different principles would result if fraternal sentiments were given their due place at the outset, so to speak and (ii) the idea that the principles of justice are merely formal, i.e. that they need to be supplemented by fraternal sentiments.

As regards (i), Cohen does not really distinguish between egalitarian principles and what the idea of fraternity requires: on his view, a fraternal society would be luck-egalitarian. This is his substitution for Rawls's difference principle in TJ that we have discussed, and rejected, above. However, the additional thought, as per (ii) is that even if the Difference Principle 
were the right principle of justice, something would still be missing from a Rawlsian theory of justice. And this is the internal tension that Cohen finds between Rawls's limitation of principles to the basic structure of society, on the one hand, and Rawls's own espousal of the ethos of fraternity, on the other. To be exact, there are two targets of criticism. First, individuals are not properly motivated by the ideal of fraternal solidarity in the Rawlsian story. And second, as a result of this, a social ethos of fraternity cannot be cultivated among citizens.

We should acknowledge that there is something plausible in this position, and in the aspiration to formulate an ideal of fraternity which can be espoused by individuals, and which can also inform social cooperation between them. Cohen's insight is that a merely legal and 'structural' reading of Rawlsian principles is an impoverished conception of justice. Rawlsian principles of justice may be conceived to apply to the Basic Structure, but that surely cannot mean that justice is limited to mere legal constraints such as taxation.

However, when we treat these aspirations as a critique of Rawls, it becomes less compelling. There is no reason within Rawls's own approach to adopt the strictly 'structural' reading, with its overly narrow understanding of what justice demands. Indeed, a proper attention to Rawls's lines on fraternity in the third part of TJ shows such a reading is inadequate to the text.

To recognize the proper role of fraternity in Rawls's thinking, we need to separate out questions about what might be our initial motivations to enter into a just society, or to act justly, and what sentiments we might have within a well-ordered society which are such as to preserve or make stable just ways of living.

One problem we saw with the comments Rawls makes in the first part of TJ regarding the ideal of fraternity is that there is no explanation of the relation between definite moral and legal requirements imposed by the Difference Principle and fraternal sentiments. However, in the third part of TJ, Rawls returns to fraternity, and there he delineates the connexion between sentiments and requirements of fraternity. Rawls provides this elucidation in the section devoted to stability (§ 76): briefly, he suggests that sentiments of fraternity can be cultivated through principles which can be justified to all, and in particular to the least well-off. The suggestion, therefore, is that an ethos of fraternity is what results from appropriately justifiable principles of justice. And in turn, Rawls sees the existence of a fraternal ethos as one of the necessary elements of stability of just principles.

Rawlsian contractualism is anti-consequentialist: it contrasts with theories which are focused on features of state of affairs, such as that they maximize welfare or equality. However, one political impulse that Rawls shares with utilitarians and with egalitarians is that a just society is one in which the needs of the least well off receive proper attention. In Rawlsian terms, a just society is one in which social cooperation guarantees to each individual, especially the worst off, an adequate scheme of liberties, opportunities and resources to flourish. In order to fulfil that role a conception of justice needs to be stable: just institutions need to be preserved. 'To insure stability [of a just scheme of cooperation] men must have a sense of justice or a concern for those who would be disadvantaged by their defection, preferably both.' (TJ, p, 435)

More specifically, Rawls considers that three conditions must be fulfilled for a conception of justice to be stable: it must be 'perspicuous to our reason, congruent with our good, and rooted not in abnegation but in affirmation of the self.' (TJ, p. 436) Thus in contrast 
to utilitarianism (and also to any egalitarianism similarly focused on states of affairs), Rawlsian contractualism is a conception of the political order such that:

(i) it is justifiable to each person: each individual can have a clear awareness of the reasons in support of the political principle of fraternity;

(ii) claims of individuals cannot be neglected or overridden for the sake of aggregated benefits or state of affairs; and

(iii) individuals can adopt it and conform to it without abnegation, self-denial or excessive sacrifice.

All three aspects are essential, and contrast with rival views such as utilitarianism or the egalitarianism of luck egalitarians. There are several contrasts with rival views. First, Rawlsian fraternity does not appeal to the impersonal goodness of state of affairs (the aggregate of well-being, or maximizing equality). In its place, it formulates an ideal of reciprocity which builds on our capacity of appreciation of the good of others as echoing our own claims. Second, there is no ad hoc balance to be stricken between altruism understood as abnegation and selfish claims of individuals. Instead, others with whom we share social institutions, caught in the same boat as us, so to speak, can quite properly make demands on us for their needs to be met; and we in turn can expect and demand that our needs should also be met by others. In this context, the idea of fraternity is essentially a reciprocal concern for the good of each person. Reciprocity of concern aims at giving each person 'a secure sense of their own worth', and that in turn 'forms the basis for the love of humankind' (TJ, p. 438).

The effect of [the difference principle and its relation to the idea of fraternity] is to heighten the operation of the reciprocity principle. As we have noted, a more unconditional caring for our good and a clearer refusal by others to take advantage of accident and happenstance, must strengthen our self-esteem; and this greater good must in turn lead to a closer affiliation with persons and institutions by way of an answer in kind. (TJ, p. 437)

For Rawls, ideals of reciprocity and solidarity that the Difference Principle embodies offer protection to each individual. In addition, the public knowledge that our shared institutions are built to meet the needs of each individual encourages the development of an ethos of fraternity.

Rawls can agree, therefore, that 'justice requires an ethos governing daily choice which goes beyond one of obedience to just rules' (Cohen, 2000: 136). But unlike his critics he offers a compelling version of the possibility and genesis of such an ethos. ${ }^{7}$

7 Compare the effects of lacking accounts of motivation in utilitarianism: 'The concern which is expressed for all persons by counting each as one (by weighing everyone's utility equally) is weak compared to that conveyed by the principles of justice. Thus the attachments generated within a well-ordered society regulated by the utility criterion are likely to vary widely between one sector of society and another. Some groups may acquire little if any desire to act justly (now defined by the utilitarian principle) with a corresponding loss in stability.' (TJ, p. 437) One contention of my article is that a similar remark holds, a fortiori, for a concern with equality as a feature of states of affairs. 
So far, I have presented an exegesis and defence of a Rawlsian conception of the political ideal of fraternity, and its attention to an ethos of fraternal relations. I have highlighted the relation of the Difference Principle to distributions of resources which are necessary for the flourishing of each member of the political community. In conclusion of this section let me highlight some aspects which seem particularly attractive of this take on the political ideal of fraternity.

Some philosophers see their role as laying down the rules of the ideal city. By contrast, Rawls begins from certain features of human societies and hypotheses about our moral psychology to envisage what the characteristics of a just society might be. For Rawls, as for Hume, justice is an artificial virtue which is made both possible and necessary by certain features of human societies. Like Hume, Rawls considers that human beings are such that they have a sense of solidarity and benevolence towards each other; that sentiment is however weak: hence the need for the artifice that rules of justice provide. This is Rawls's first empirical hypothesis: the fact of a weak sense of benevolence of human beings towards each other makes justice both possible and necessary. In the context of each political community, this initial sentiment manifests itself in an inclination to meet the needs of the badly-off; in the same manner, sisters and brothers in a family often tend to help the badly off among them. Call this first rationale 'the lifeboat': the idea that morality requires that we meet the needs of the badly-off, at least within the political community.

This initial fraternal inclination is however not operative without a favourable institutional framework. Again, Rawls no less than Hume stresses the artificial nature of political society and that its virtues lie in this artifice. A political society, if well run, ought to have institutions such that the badly-off receive the necessary resources for flourishing. Given limited resources, a proper attention to the need of the least well-off will render certain inequalities problematic. If some enjoy superfluous goods whilst the needs of others are unmet, society is not well run. This tendency towards lesser inequality is supplemented by a further thought: if people in a given society cooperate to produce goods and services, they should receive a just share of the product of their social cooperation. Call this second rationale 'the boat we built': fairness requires that the least well-off do as well as possible. Enter the principle of fraternity: social and economic inequalities are to be to the greatest benefit of the least-advantaged members of society.

To these initial points, Rawls adds two further empirical hypotheses. The first hypothesis regards what we all care about or value in the institutions that we live within, namely that how they run be justifiable to each and every one of us; that principles meet this condition is something we value. The principle of fraternity, or that is to say, the Difference Principle, meets that demand for justification. Rather than an exhortation to the better-off that they do more to deliver more welfare or to maximize equality, it is a principle that can be shared by the better-off and the least well-off: all can see it as a rule which expresses an interest they have that society be run to meet the needs of each, the needs of all. (Arguably this empirical element is what is missing from Kant's view of the possibility of a just constitution for a people of demons.)

The final empirical hypothesis is that the weak sentiment of benevolence present in human beings is fortifiable by rules which are publicly justified and regarded as just. Hence the idea which we saw in the last section of an ethos of fraternity. The good which results 
from the Difference Principle is a shared fraternal ethos: an endorsement of shared norms of cooperation; and this in turn makes rules of justice more stable, though approval of compliance with the rules. A just society, thinks Rawls, is one in which members shape their society together. The have-nots see themselves in a position to claim resources on the basis of this collective enterprise: society does not only do the best by them, but it is also a society which they partake in shaping. In turn, the haves see it as reasonable for the have-nots to make that claim, because they identify with the community as a collective enterprise, and see their interest in a well-run society satisfied. Organizing a society alongside the difference principle thus results in all seeing themselves as properly belonging.

\section{Conclusion}

At the beginning of this article, I mentioned criticisms which represent Rawlsian theory as addressed to selfish motivations, insufficiently egalitarian and deaf to social dimensions of a just society. By contrast, we saw that sentiments can play a role not only in the explanation of circumstances of justice, and so in the initial conditions from which justice is made possible and constructed, but also in providing a social glue to keep a just society going once set up. This is the key role Rawls attributes to fraternity: sentiments of fraternity do not have a foundational role, and are excluded from the description of the veil of ignorance and the way we arrive at the Difference Principle; however it has the role of ongoing social cement, and so offers the possibility of re-interpreting the double significance of the Difference Principle.

In subsequent work, Rawls abandons any reference to fraternity, and focuses instead on solidarity. Fraternity comes associated with other collateral ideas, from the family to religious and revolutionary sentiments, through the solidarity enjoyed by members of guilds in the middle ages. What remains after TJ is the focus on reciprocity and justification of institutions to each member of political society, and on the need to find principles which leave no one with the sentiment that they are 'left behind'. And that seems the most plausible way of rendering the elusive but appealing political ideal of fraternity. ${ }^{8}$

\section{References}

Anderson, E. (1999) 'What is the Point of Equality?', Ethics, Vol. 109, No. 2, pp. 287-337. Cohen, G. A. (1989) 'On the Currency of Egalitarian Justice', Ethics, Vol. 99, No. 4, pp. 906-944.

Cohen, G. A. (1992) 'Incentives, Inequality and Community', in G. Peterson (ed.), The Tanner Lectures on Human Values, vol 13, Salt Lake City: University of Utah Press, pp. 263-329.

Cohen, G. A. (1997) 'Where the Action Is: On the Site of Distributive Justice', Philosophy \& Public Affairs, Vol. 26, Issue 1, pp. 3-30.

Cohen, G. A. (2008) Rescuing Justice and Equality, Cambridge Mass.: Harvard University Press.

8 See for example the justification of the difference principle in JFR, p. 128ff. For an exploration of an anticonsequentialist conception of the political value of solidarity, see (Wiggins, 2009). 
David, M. (1987) Fraternité et Révolution française, Paris: Aubier.

David M. (1992), Le printemps de la fraternité: genèse et vicissitudes 1830-1851, Paris: Aubier.

Estlund, D. (1998) 'Liberalism, Equality and Fraternity in Cohen's critique of Rawls', Journal of Political Philosophy, Vol. 6, Issue 1, pp. 99-112.

Frankfurt, H. (1987) 'Equality as a Moral Ideal', Ethics, Vol. 98, No. 1, pp. 21-43.

Munoz-Dardé, V. (1998) 'John Rawls, Justice in and Justice of the Family', The Philosophical Quarterly, Vol. 48, No 192, pp. 335-35.

Munoz-Dardé, V. (2005) 'Equality and Division: Values in Principle', Proceedings of the Aristotelian Society, supplementary volume 79, pp. 255-284.

Munoz-Dardé, V. (2014) 'Luck Egalitarianism', Rawls Lexicon, eds David Reidy and Jon Mandle, Cambridge University Press, pp. 471-480.

Nozick, R. (1974) Anarchy, State, and Utopia, New York: Basic Books.

Rawls, J. (1971) A Theory of Justice, Cambridge Mass.: Harvard University Press, Revised edition 1999.

Rawls, J. (1999) 'Social Unity and Primary Goods', Collected Papers, ed. Samuel Freeman, Cambridge Mass.: Harvard University Press, pp. 369-370.

Rawls, J. (2001) Justice as Fairness: A Restatement, Cambridge, Mass: Harvard University Press, edited by Erin Kelly.

Sandel, M. (1982) Liberalism and the limits of justice, Cambridge: Cambridge University Press.

Scheffler. S. (2003) 'What is Egalitarianism', Philosophy \& Public Affairs, Vol. 31, No 1, pp. 5-39.

Temkin, L. (2003) ‘Egalitarianism Defended', Ethics, vol. 113, pp. 764-782.

Wiggins, D. (2009) 'Solidarity and the Root of the Ethical', Tijdschrift voor Filosofie, 71, No 2, pp. 239-269. 
